\title{
ANTIMICROBIAL ACTIVITIES OF CHITOSAN NANOPARTICLES PREPARED FROM LUCILIA CUPRINA MAGGOTS (DIPTERA: CALLIPHORIDAE)
}

\author{
By \\ MOSTAFA I. HASSAN ${ }^{1 *}$, ALY F. MOHAMED ${ }^{2}$, FATMA A. TAHER ${ }^{3}$ \\ AND MOHAMMAD R. KAMEL ${ }^{1}$
}

Department of Zoology and Entomology, Faculty of Science ${ }^{1}$ and Department of

Chemistry, Faculty of Science (Girls) ${ }^{3}$, Al-Azhar University, Nasr City and

Applied Researches Sector, VACSERA ${ }^{2}$, Giza, Egypt

( ${ }^{*}$ Correspondence:mostafa012@gmail.com)

\begin{abstract}
Chitosan nanoparticles were studied as antimicrobial agent. The antibacterial activity of chitosan nanoparticles were investigated against three Gram-negative bacteria; Escherichia coli, Pseudomonas aeruginosa and Salmonella typhi, and three Gram-positive bacteria; Staphylococcus aureus, Enterococcus faecalis and Streptococcus pyogenes. The antifungal activity were examined against three fungi; Geotrichum candidum, Candida krusei and Candida parapsilosis. The antiviral activities were tested against three viruses; Rift Valley Fever (RVFV), Herpes simplex-1 (HSV-1) and Coxsackie viruses. Chitosan nanoparticles were inhibited all bacteria and fungi except $E$. faecalis seemed to be resistant strain. Infectivity titers of all viruses were reduced by chitosan nanoparticles, which are a natural antimicrobial agent.
\end{abstract}

Keywords: Antimicrobial activities, Chitosan, Nanoparticles, Lucilia cuprina, Maggots

\section{Introduction}

Dipterous insects such as mosquitoes and flies are vectors for many pathogens such as protozoa, nematodes, bacteria, fungi and viruses. $\mathrm{Cu}$ lex pipiens is a common mosquito species in Egypt which representing a vector for Wuchereria bancrofti that causes filariasis or elephantiasis (Khalil et al, 1930; Gad et al, 1996), West Nile Virus (Taylor et al, 1956; Dohm et al, 2002), and Rift Valley Fever Virus (Meagan et al, 1980; Darwish and Hoogastraal, 1981; Turell et al, 1996; Tantely et al, 2015).

Flies are very dangerous vector of many diseases such as typhoid, cholera, anthrax, diarrhea, dysentery, African sleeping sickness and etc. Also the flies attracted to the host by the sensilla and may feed on the host tissues or body fluids and may causes myiasis by their maggots. On the other side, the maggots of Lucilia sericata and Lucilia cuprina (Diptera: Calliphoridae) used for treatment of wounds which called maggot debridement therapy (Gottrup and Jørgensen, 2011; Sherman et al, 2013; Hassan et al, 2014). Maggots inhibit many bacterial strains such as Escherichia coli, Pseudomonas aeruginosa, Proteus vulgaris, Staphylococcus aureus and S. pyogenes contaminating wounds (Giacometti et al, 2000; Raza et al, 2013; Alharbi and Zayed, 2014). The maggots were used for preparation of chitosan the powerful antimicrobial agent.
The present study aimed to evaluate the antibacterial, antifungal and antiviral activities of chitosan nanoparticles prepared from Lucilia cuprina maggots.

\section{Materials and methods}

Chitosan preparation and characterization: Chitosan and chitosan nanoparticles were carried out (Hassan et al, 2016). The degree of deacetylation (DDA) of chitosan was $80.5 \%$.

Antibacterial activity of chitosan nanoparticles against three Gram-nega-tive bacteria strains; Escherichia coli (RCMB 010052-6), Pseudomonas aeruginosa (RCMB 01002 43-5) and Salmonella typhi (RCMB 01002 15-4), and three Gram-positive bacteria strains Staphylococcus aureus (RCMB 01001 83-9), Enterococcus faecalis (RCMB 01001 54-2) and Streptococcus pyogenes (RCMB 01001 74-2) were evaluated by microdilution method (Hassan et al, 2016).

Antifungal activity of chitosan nanoparticles against three fungi; Geotrichum candidum (RCMB 05097), Candida krusei (RCMB 05098) and C. parapsilosis (RCMB 05073) were evaluated by microdilution method at Microbiology Unit, The Regional Center of Mycology and Biotechnology, Al-Azhar University.

Chitosan nanoparticles were dissolved in acetic acid $1 \%(\mathrm{v} / \mathrm{v})$ and diluted to a concentration of $8 \mathrm{mg} / \mathrm{ml}$, further 1:2 serial dilutions were per- 
formed by addition of culture broth to reach concentrations ranging from 8000 to $0.49 \mu \mathrm{g} / \mathrm{ml}$.

A quantity of $5 \mu \mathrm{l}$ of each dilution was distributed in 96 well plates, as well as a sterility control and a growth control (containing culture broth plus acetic acid $1 \%(\mathrm{v} / \mathrm{v})$, without antimicrobial substance). Each test and growth control wells were inoculated with $5 \mu 1$ of microbial suspension $\left(10^{4} \mathrm{CFU} / w e l l\right)$. All experiments were performed in triplicate and the microdilution trays were incubated at $37^{\circ} \mathrm{C}$ for $24 \mathrm{~h}$ according to the method of Souza, et al. (2005).

Ten $\mu 1$ of 3- (4,5-Dimethylthiazol-2-yl)-2,5diphenyltetrazolium bromide (MTT) solution $(5 \mathrm{mg} / \mathrm{ml})$ were added to each well and the plates was re-incubated for $3 \mathrm{~h}$ at $37^{\circ} \mathrm{C}$. Fifty $\mu \mathrm{l}$ of Dimethyl sulfoxide (DMSO) solution were added to wells and microbial growth was detected by optical density (ELISA reader, Tecan, Sunrise).

Cell culture: Vero cells line of adult African green monkey kidney (American tissue culture collection, USA) were supplied by Tissue Culture Department, VACSERA. Vero cells were grown in minimum essential medium with Earle's Salts (MEME) supplemented with 10\% fetal calf serum (FCS) (GEPCO, USA), 100 $\mu \mathrm{g} /$ $\mathrm{ml}$ penicillin and $10 \mu \mathrm{g} / \mathrm{ml}$ streptomycin.

Cytotoxicity: Cell viability of Vero cells under the effect of chitosan nanoparticles was carried out (Mosmann, 1983) and measured with spectrophotometer (ELISA microplate reader) BioTek, ELx800 at a wavelength 570nm. Cell viability\% was calculated by the following equation: Viability\% $=($ mean optical density of tested sample/mean optical density of control) $\times 100$.

The antiviral activities of chitosan nanoparticles against Rift Valley Fever, Herpes simplex (Type 1) and Coxsackie viruses were determined to evaluate the infectivity titer in Vero cells after Hassan, et al. (2015) at the laboratory of Virology at the Holding Company for Production of Vaccines and Biological Products (VACSERA).

\section{Results}

Complete inhibition percentage (100) of Escherichia coli was recorded at concentrations: $8000,4000,2000,1000 \& 500 \mu \mathrm{g} / \mathrm{ml}$, and decreased gradually at lowest concentrations until no inhibition recorded at concentrations 3.9, $1.95,0.98 \& 0.49 \mu \mathrm{g} / \mathrm{ml}$. Chitosan nanoparticles showed $100 \%$ inhibition against Salmonella typhi at concentrations 8000, 4000, 2000, 1000 $\& 500 \mu \mathrm{g} / \mathrm{ml}$ and showed $92.65 \%, 84.27 \%$, $63.75 \%, 47.68 \%, 35.68 \%, 23.62 \%$ \& $16.79 \%$ inhibitions at concentrations: $250,125,62.5$, $31.25,15.63,7.81 \& 3.9 \mu \mathrm{g} / \mathrm{ml}$, respectively.

Pseudomonas aeruginosa was showed resistance to chitosan nanoparticles more than $E$. coli and S. typhi, where, the effect of chitosan nanoparticles was detected at 8000,4000 \& $2000 \mu \mathrm{g} / \mathrm{ml}$ and showed $50.68 \%, 36.75 \%$ and $15.68 \%$ inhibitions, respectively (Tab. 1; Fig. 1).

Chitosan nanoparticles were showed complete inhibition percentage (100) against Staphylococcus aureus at concentrations: $8000 \& 4000 \mu \mathrm{g} /$ $\mathrm{ml}$ and decreased gradually with decreasing concentrations giving $92.65 \%, 88.33 \%, 71.55 \%$, $50.64 \%, 37.24 \% \& 8.68 \%$ inhibition at concentrations: 2000, 1000, 500, 250, $125 \& 62.5 \mu \mathrm{g} /$ $\mathrm{ml}$, respectively, without inhibition at concentrations: $31.25,15.63,7.81,3.9,1.95,0.98 \&$ $0.49 \mu \mathrm{g} / \mathrm{ml}$. Antibacterial activity of chitosan nanoparticles against Streptococcus pyogenes was observed at $125 \mu \mathrm{g} / \mathrm{ml}$ and increased until $100 \%$ inhibition at $8000 \mu \mathrm{g} / \mathrm{ml}$ (Tab. 2; Fig. 2). Enterococcus faecalis was resistant strain to chitosan nanoparticles.

Table 1: Antibacterial activity of chitosan nanoparticles against Escherichia coli, Pseudomonas aeruginosa \& Salmonella typhi.

\begin{tabular}{|c|c|c|c|}
\hline \multirow{2}{*}{$\begin{array}{c}\text { Concentration } \\
\mu \mathrm{g} / \mathrm{ml})\end{array}$} & Escherichia coli & Pseudomonas aeruginosa & Salmonella typhi \\
\cline { 2 - 4 } & 100 & 50.68 & 100 \\
\hline 8000 & 100 & 36.75 & 100 \\
\hline 4000 & 100 & 15.68 & 100 \\
\hline 2000 & 100 & - & 100 \\
\hline 1000 & 100 & - & 92.65 \\
\hline 500 & 89.64 & - & 84.27 \\
\hline 250 & 73.65 & - & 63.75 \\
\hline 125 & 61.57 & - & 47.68 \\
\hline 62.5 & 43.68 & - & 35.68 \\
\hline 31.25 & 36.76 & - & 23.62 \\
\hline 15.63 & 17.49 & - & 16.79 \\
\hline 7.81 & - & - & - \\
\hline 3.9 & - & - & - \\
\hline 1.95 & - & - & - \\
\hline 0.98 & - & - & \\
\hline 0.49 & & & \\
\hline
\end{tabular}


Table 2: Antibacterial activity of chitosan nanoparticles against Staphylococcus aureus, Enterococcus faecalis and Streptococcus pyogenes.

\begin{tabular}{|c|c|c|c|}
\hline \multirow{2}{*}{$\begin{array}{c}\text { Concentration } \\
(\mu \mathrm{g} / \mathrm{ml})\end{array}$} & \multicolumn{3}{|c|}{ Inhibition (\%) } \\
\hline & Staphylococcus aureus & Enterococcus faecalis & Streptococcus pyogenes \\
\hline 8000 & 100 & - & 100 \\
\hline 4000 & 100 & - & 90.14 \\
\hline 2000 & 92.65 & - & 80.33 \\
\hline 1000 & 88.33 & - & 62.76 \\
\hline 500 & 71.55 & - & 43.68 \\
\hline 250 & 50.64 & - & 23.69 \\
\hline 125 & 37.24 & - & 8.76 \\
\hline 62.5 & 8.68 & - & - \\
\hline 31.25 & - & - & - \\
\hline 15.63 & - & - & - \\
\hline 7.81 & - & - & - \\
\hline 3.9 & - & - & - \\
\hline 1.95 & - & - & - \\
\hline 0.98 & - & - & - \\
\hline 0.49 & - & - & - \\
\hline
\end{tabular}

Antifungal activity: Geotrichum candidum was a sensitive strain to chitosan nanoparticles which produced $87.66 \%, 71.65 \%, 59.37 \%, 51.24 \%$, $36.76 \% \& 7.49 \%$ inhibition at concentrations of $1000,500,250,125,62.5 \& 31.25 \mu \mathrm{g} / \mathrm{ml}$, respectively. Complete inhibition $(100 \%)$ was produced at the higher concentrations: 2000, 4000 $\& 8000 \mu \mathrm{g} / \mathrm{ml}$, while the concentrations lowest than $31.25 \mu \mathrm{g} / \mathrm{ml}$ didn't produce inhibition. Chitosan nanoparticles showed $100 \%$ inhibition against Candida krusei at concentration $8000 \mu \mathrm{g}$ $/ \mathrm{ml}$, while they showed $82.64 \%, 71.68 \%$,
$53.69 \%, 43.62 \%, 32.69 \%$ \& $15.87 \%$ inhibitions at concentrations: $4000,2000,1000,500,250 \&$ $125 \mu \mathrm{g} / \mathrm{ml}$, respectively.

The effect of chitosan nanoparticles on Candida parapsilosis was began at concentration $125 \mu \mathrm{g} / \mathrm{ml}$ and showed $31.03 \%$ inhibition, while, the concentrations $250,500,1000 \& 2000 \mu \mathrm{g} / \mathrm{ml}$ recorded $50.68 \%, 62.79 \%, 69.39 \%$ \& $85.69 \%$ inhibition, respectively. The completely inhibition of Candida parapsilosis was recorded at concentrations: 4000 and $8000 \mu \mathrm{g} / \mathrm{ml}$ (Tab. 3; Fig. 3).

Table3: Antifungal activity of chitosan nanoparticles against Geotrichum candidum, Candida krusei and Candida parapsilosis

\begin{tabular}{|c|c|c|c|}
\hline \multirow{2}{*}{$\begin{array}{c}\text { Concentration } \\
(\mu \mathrm{g} / \mathrm{ml})\end{array}$} & \multicolumn{3}{|c|}{ Inhibition (\%) } \\
\hline 8000 & Geotrichum candidum & Candida krusei & Candida parapsilosis \\
\hline 4000 & 100 & 100 & 100 \\
\hline 2000 & 100 & 82.64 & 100 \\
\hline 1000 & 100 & 71.68 & 69.39 \\
\hline 500 & 87.66 & 53.69 & 62.79 \\
\hline 250 & 71.65 & 43.62 & 50.68 \\
\hline 125 & 59.37 & 32.69 & 31.03 \\
\hline 62.5 & 51.24 & 15.87 & - \\
\hline 31.25 & 36.76 & - & - \\
\hline 15.63 & 7.49 & - & - \\
\hline 7.81 & - & - & - \\
\hline 3.9 & - & - & - \\
\hline 1.95 & - & - & - \\
\hline 0.98 & - & - & - \\
\hline 0.49 & - & - & \\
\hline
\end{tabular}

Antiviral activities: Regarding to the evaluation of chitosan nanoparticles cytotoxicity on Vero cell line, the present data showed that, the viability of Vero cells was inversely proportional with the concentration of chitosan nanoparticles solution. The safe concentration of chitosan nanoparticles solution which used in the antiviral investigations was observed to be $60 \mu \mathrm{g} / \mathrm{ml}$. The virus infectivity titer of Rift Valley fever virus on
Vero cell (pre-treatment as control) was 6.66 $\log (10) / 0.1 \mathrm{ml}$, while, the virus infectivity titer of RVFV on Vero cell treated with chitosan nanoparticles (post-treatment) was 5 $\log (10) / 0.1 \mathrm{ml}$. The $\log$ difference was 1.6 with reduction of $24.9 \%$. The chitosan nanoparticles reduced the infectivity titer of Herpes simplex-1 (HSV-1) on Vero cell from $5.32 \log (10) / 0.1 \mathrm{ml}$ to $4.32 \mathrm{log}$ (10)/0.1 $\mathrm{ml}$ with one $\log$ difference and the 
reduction percent was $18.8 \%$. Reduction of infectivity titer of Coxsackie virus on Vero cell was observed with chitosan nanoparticles, where, the infectivity titer of Coxsackie virus pre-treatment was $3.83 \log (10) / 0.1 \mathrm{ml}$, and infectivity titer of Coxsackie virus posttreatment was $2.83 \log (10) / 0.1 \mathrm{ml}$ (Tab. 4; Fig. 4). The reduction percent was $26.1 \%$.

Table 4: Antiviral activity of chitosan nanoparticles against Rift Valley Fever (RVFV), Herpes simplex-1 (HSV-1) and Coxsackie viruses.

\begin{tabular}{|c|c|c|c|}
\hline virus & $\begin{array}{c}\text { Titer pre-treatment } \\
\log (10) / 0.1 \mathrm{ml}\end{array}$ & $\begin{array}{c}\text { Titer post-treatment } \\
\log (10) / 0.1 \mathrm{ml}\end{array}$ & Log difference \\
\hline Rift Valley fever virus & 6.66 & 5 & 1.66 \\
\hline Herpes simplex-1 virus & 5.32 & 4.32 & 1 \\
\hline Coxsackie virus & 3.83 & 2.83 & 1 \\
\hline
\end{tabular}

\section{Discussion}

Antibacterial activity: The antibacterial assay of chitosan nanoparticles against Gram-negative and Gram-positive bacteria was applied with different concentrations. Chitosan nanoparticles were showed antibacterial activities against Gram-negative and Gram-positive bacteria. The inhibition percentages were directly proportional with the chitosan nanoparticles concentrations. Generally, the Gram-negative bacteria were more sensitive to chitosan nanoparticles than Gram-positive bacteria.

The results agreed with Liu et al. (2001); Qi et al. (2004); Balicka-Ramisz et al. (2005); Fujimoto et al. (2006); Liu et al. (2006); Andres et al. (2007); Jing et al. (2007); Chung and Chen (2008); Mohy eldin et al. (2008); Li et al. (2010); Tang et al. (2010); Tayel et al. (2010a); Islam et al. (2011b); Benhabiles et al. (2012); Younes et al. (2014) and Ma (2015), the chitosan was showed antibacterial activity against Escherichia coli.

In the present study, the chitosan showed antibacterial activity against Pseudomonas aeruginosa, this result was similar with that of Balicka-Ramisz et al. (2005); Andres et al. (2007); Jing et al. (2007); Chung and Chen (2008); Mohy eldin et al. (2008); Tayel et al. (2010a); Tao et al. (2011) and Benhabiles et al. (2012).

Qi et al. (2004); Balicka-Ramisz et al. (2005); Tayel et al. (2010a); Islam et al. (2011a); Benhabiles et al. (2012); Rodrigues-Nunes et al. (2012) and Younes et al. (2014) recorded the antibacterial activities of chitosan against Salmonella sp., these records were hassling with the antibacterial activity of chitosan nanoparticles against Salmonella typhi obtained in the present study.

Corresponding with the findings of Liu et al. (2001); Qi et al. (2004); Balicka-Ramisz et al. (2005); Fujimoto et al. (2006); Jing et al. (2007); Tayel et al. (2010a); Islam et al. (2011a; 2011b);
Tao et al. (2011); Benhabiles et al. (2012); Rodrigus-Nunez et al. (2012); Salmabi and Seema (2013); Van Toan et al. (2013) and Younes et al. (2014), the Staphylococcus aureus was inhibited with chitosan. In addition, Streptococcus pyogenes were inhibited also by chitosan nanoparticles as observed in the present study. In agreement with Younes et al. (2014), Enterococcus faecalis was resistant strain to chitosan.

Antifungal activity agreed with Yien et al. (2012), the chitosan nanoparticles were observed to be natural antifungal agents. The antifungal activity of chitosan against Geotrichum candidum, Candida krusei and Candida parapsilosis in the present study were similar with Candida albicans (Balicka-Ramisz et al, 2005; Seyfarth et al, 2008; Ballal et al, 2009; Tayel et al, 2010b), Candida tropicalis (Allan and Hadwiger, 1979), Candida krusei and Candida glabrata (Seyfarth et al, 2008).

In the present work, the chitosan nanoparticles showed antiviral activity and protect the Vero cells from cytopathic effect of viruses compared with the control, this finding corresponded to Chirkov (2002) who reported that, chitosan have antiviral activity and suppress the viral infection. The antiviral activities of chitosan nanoparticles against Rift Valley fever, Coxsackie viruses as RNA virus and Herpes simplex-1virus as DNA virus were hassling with the result of Artan et al. (2008) on Lentivirus human immunodeficiency virus 1 (HIV-1).

In this study, the chitosan prepared from maggots of Lucilia cuprina was showed antiviral activities on tested viruses and this similar with the result of chitosan prepared from Musca domestica maggots on the Bombyx mori nuclear polyhydrosis virus (Ai et al, 2012).

\section{Conclusion}

The antibacterial, antifungal and antiviral activities of chitosan nanoparticles evaluated in this study. The chitosan nanoparticles were inhibited the growth of all tested Gram-negative 
bacteria strains; Escherichia coli, Pseudomonas aeruginosa and Salmonella typhi and two Grampositive bacteria strains Staphylococcus aureus and Streptococcus pyogenes, while the Enterococcus faecalis was seemed to be resistant strain. Antifungal activity of chitosan nanoparticles were observed against Geotrichum candidum, Candida krusei and Candida parapsilosis. Infectivity titers of tested viruses; Rift Valley fever, Coxsackie viruses as RNA virus and Herpes simplex-1virus as DNA virus were reduced by chitosan nanoparticles.

\section{References}

Ai, H, Wang, F, Xia, Y, Chen, X, Lei, C, 2012: Antioxidant, antifungal and antiviral activities of chitosan from the larvae of housefly, Musca domestica L. Food Chem. 132, 1:493-8.

Alharbi, SA, Zayed, ME, 2014: Antibacterial susceptibility of bacteria isolated from burns and wounds of cancer patients. J. Saudi Chem. Soc. 18, 1:3-11.

Allan, CR, Hadwiger, LA, 1979: The fungicidal effect of chitosan on fungi of varying cell wall composition. Exp. Mycol. 3, 3:285-7.

Andres, Y, Giraud, L, Gerente, C, Le Cloirec, P, 2007: Antibacterial effects of chitosan powder: mechanisms of action. Environ. Technol. 28, 12:1357-63.

Artan, M, Karadeniz, F, Kim, MM, Kim, SK, 2008: Chitosan derivatives as HIV-1 inhibitors. J. Biotechnol. 136: S539-42.

Balicka-Ramisz, A, Wojtasz-Pajak, A, Pilarczyk, B, Ramisz, A, Laurans, L, 2005: Antibacterial and antifungal activity of chitosan. Int. Soc. Anim. Hyg. (ISAH) 2: 406-8.

Ballal, NV, Kundabala, M, Bhat, KS, Acharya, S, Ballal, M, et al, 2009: Susceptibility of Candida albicans and Enterococcus faecalis to chitosan, chlorhexidine gluconate and their combination in vitro. Aust. Endod. J. 35, 1:2933.

Benhabiles, MS, Salah, R, Lounici, H, Drouiche, N, Goosen, MFA, et al, 2012: Antibacterial activity of chitin, chitosan and its oligomers prepared from shrimp shell waste. Food Hydrocoll. 29, 1:48-56.

Chirkov, SN, 2002: The antiviral activity of chitosan (review). Appl. Biochem. Microbiol. 38, 1: 1-8

Chung, YC, Chen, CY, 2008: Antibacterial characteristics and activity of acid-soluble chitosan. Bioresour. Technol. 99, 8:2806-14.

Darwish, M, Hoogstraal, H, 1981: Arboviruses infesting human and lower animals in Egypt, A review of thirty years of research. J. Egypt. Publ. Hlth. Assoc. 56:1-12.

Dohm, DJ, Sardelis, MR, Turell, MJ, 2002: Experimental vertical transmission of West Nile virus by Culex pipiens (Diptera: Culicidae). J. Med. Entomol. 39, 4:640-4.

Fujimoto, T, Tsuchiya, Y, Terao, M, Nakamura, K, Yamamoto, M, 2006: Antibacterial effects of Chitosan solution ${ }^{\circledR}$ against Legionella pneumophila, Escherichia coli, and Staphylococcus aureus. Int. J. Food Microbiol. 112, 2:96101.

Gad, AM, Hammad, RE, Farid, HA, 1996: Uptake and development of Wucheria bancrofti in Culex pipiens L. and Aedes caspius Pallas. J. Egypt. Soc. Parasitol. 26, 2:305-14.

Giacometti, A, Cirioni, O, Schimizzi, AM, Del Prete, MS, Barchiesi, F, et al, 2000: Epidemiology and microbiology of surgical wound infections. J. Clin. Microbiol. 38, 2:918-22.

Gottrup, F, Jørgensen, B, 2011: Maggot debridement: an alternative method for debridement. Eplasty 11, 290-302

Hassan, MI, Hammad, KM, Fouda, MA, Kamel, MR, 2014: The using of Lucilia cuprina maggots in the treatment of diabetic foot wounds. J. Egypt. Soc. Parasitol. 44, 1:125-9.

Hassan, MI, Mohamed, AF, Amer, MA, Hammad, KM, Riad, SA, 2015: Monitoring of the antiviral potential of bee venom and wax extracts against Adeno-7 (DNA) and Rift Valley fever virus (RNA) viruses models. J. Egypt. Soc. Parasitol. 45, 1:193-8.

Hassan, MI, Taher, FA, Mohamed, AF, Kamel, MR, 2016: Chitosan nanoparticles prepared from Lucilia cuprina maggots as antibacterial agent. J. Egypt. Soc. Parasitol. 46, 3:51926.

Islam, MM, Masum, SM, Mahbub, KR, 2011a: In vitro antibacterial activity of shrimp chitosan against Salmonela paratyphi and Staphylococcus aureus. J. Bangladesh Chem. Soc. 24, 2:185-90.

Islam, MM, Masum, SM, Mahbub, KR, Haque, M, 2011b: Antibacterial Activity of Crab-Chitosan against Staphylococcus aureus and Escherichia coli. J. Adv. Sci. Res. 2, 4:63-6. Jing, Y, Hao, Y, Qu, H, Shan, Y, Li, D, et al, 2007: Studies on the antibacterial activities and mechanisms of chitosan obtained from cuticles of housefly larvae. Acta Biol. Hung. 58, 1:75-86. Khalil, M, Malawani, A, Hilmi, IS, 1930: The 
transmission of Bancroftian filariasis in Egypt. J. Egypt. Med. Assoc. 15: 315-32.

Li, B, Su, T, Chen, X, Liu, B, Zhu, B, et al, 2010: Effect of chitosan solution on the bacterial septicemia disease of Bombyx mori (Lepidoptera: Bombycidae) caused by Serratia marcescens. Appl. Entomol. Zool. 45, 1:145-52.

Liu, N, Chen, XG, Park, HJ, Liu, CG, Liu, CS, et al, 2006: Effect of MW and concentration of chitosan on antibacterial activity of Escherichia coli. Carbohydr. Polym. 64, 1:60-5.

Liu, XF, Guan, YL, Yang, DZ, Li, Z, Yao, KD, 2001: Antibacterial action of chitosan and carboxy- methylated chitosan. J. Appl. Polym. Sci. 79, 7:1324-35.

Ma, Z, 2015: Evaluation of antimicrobial activity of chitosan nanoparticles in different matrices from animals with disease. In 2015 Annual Meeting (July 25-28, 2015). Iafp.

Meagan, JM, Khalil, GM, Hoogstraal, H, Adham, FK, 1980: Experimental transmission and field isolation studies implicating Culex pipiens as a vector of Rift Valley virus in Egypt. Am. J. Trop. Med. Hyg. 80:1405-10.

Mohy Eldin, MS, Soliman, EA, Hashem, AI, Tamer, TM, 2008: Antibacterial activity of chitosan chemically modified with new technique. Trends Biomater. Artif. Organs, 22, 3:125-37.

Mosmann, T, 1983: Rapid colorimetric assay for cellular growth and survival: application to proliferation and cytotoxicity assays. J. Immunol. Methods, 65, 1/2:55-63.

Qi, L, Xu, Z, Jiang, X, Hu, C, Zou, X, 2004: Preparation and antibacterial activity of chitosan nanoparticles. Carbohydr. Res. 339, 16:2693700.

Raza, MS, Chander, A, Ranabhat, A, 2013: Antimicrobial susceptibility patterns of the bacterial isolates in post-operative wound infections in a tertiary care hospital, Kathmandu, Nepal. Open J. Med. Microbiol. 3, 3:159-63.

Rodríguez-Núñez, JR, López-Cervantes, J, Sánchez-Machado, DI, Ramírez-Wong, B, Torres-Chavez, P, et al, 2012: Antimicrobial activity of chitosan-based films against Salmonella typhimurium and Staphylococcus aureus. Int. J. Food Sci. Tech. 47, 10:2127-33.

Salmabi, KA, Seema, PN, 2013: Antibacterial potential of chitosan on pathogenic Gram positive cocci. Adv. Bio. Tech. 12, 10:10-3.

Seyfarth, F, Schliemann, S, Elsner, P, Hipler, UC, 2008: Antifungal effect of high-and lowmolecular-weight chitosan hydrochloride, car- boxymethyl chitosan, chitosan oligosaccharide and N-acetyl-D-glucosamine against Candida albicans, Candida krusei and Candida glabrata. Int. J. Pharm. 353, 1:139-48.

Sherman, RA, Mumcuoglu, KY, Martin Grassberger, MD, Tantawi, TI, 2013: Maggot Therapy. In: Biotherapy-History, Principles and Practice, Springer Netherlands.

Souza, SMD, Monache, FD, Smânia, A, 2005: Antibacterial activity of coumarins. Z . Naturforsch C. 60, 9/10:693-700.

Tang, H, Zhang, P, Kieft, TL, Ryan, SJ, Baker, S, et al, 2010: Antibacterial action of a novel functionalized chitosan-arginine against Gr-amnegative bacteria. Acta Biomater. 6, 7:2562-71.

Tantely, LM, Boyer, S, Fontenille, D, 2015: A review of mosquitoes associated with Rift Valley fever virus in Madagascar. Am. J. Trop. Med. Hyg. 92, 4:722-9.

Tao, Y, Qian, LH, Xie, J, 2011: Effect of chitosan on membrane permeability and cell morphology of Pseudomonas aeruginosa and Staphyloccocus aureus. Carbohydr. Polym. 86, 2:96974.

Tayel, AA, Moussa, S, Opwis, K, Knittel, D, Schollmeyer, E, et al, 2010a: Inhibition of microbial pathogens by fungal chitosan. Int. J. Biol. Macromol. 47, 1:10-4.

Tayel, AA, Moussa, S, Wael, F, Knittel, D, Opwis, K, et al, 2010b: Anticandidal action of fungal chitosan against Candida albicans. Int. J. Biol. Macromol. 47, 4:454-7.

Taylor, RM, Work, TH, Hurlbut, HS, Rizk, F, 1956: A study of the ecology of West Nile virus in Egypt. Am. J. Trop. Med. Hyg. 5, 4:579620.

Turell, MJ, Presley, SM, Gad, AM, Cope, SE, Dohm, DJ, et al, 1996: Vector competence of Egyptian mosquitoes for Rift Valley fever virus. Am. J. Trop. Med. Hyg. 54, 2:136-9.

Van Toan, N, Hanh, TT, Thien, PVM, 2013: Antibacterial activity of chitosan on some common food contaminating microbes. Open Biomater. J. 4, 1:1-5.

Yien, L, Zin, NM, Sarwar, A, Katas, H, 2012: Antifungal activity of chitosan nanoparticles and correlation with their physical properties. Int. J. Biomater. 2012:1-9.

Younes, I, Hajji, S, Frachet, V, Rinaudo, M, Jellouli, K, et al, 2014: Chitin extraction from shrimp shell using enzymatic treatment: Antitumor, antioxidant and antimicrobial activities of chitosan. Int. J. Biol. Macromol. 69:489-98. 


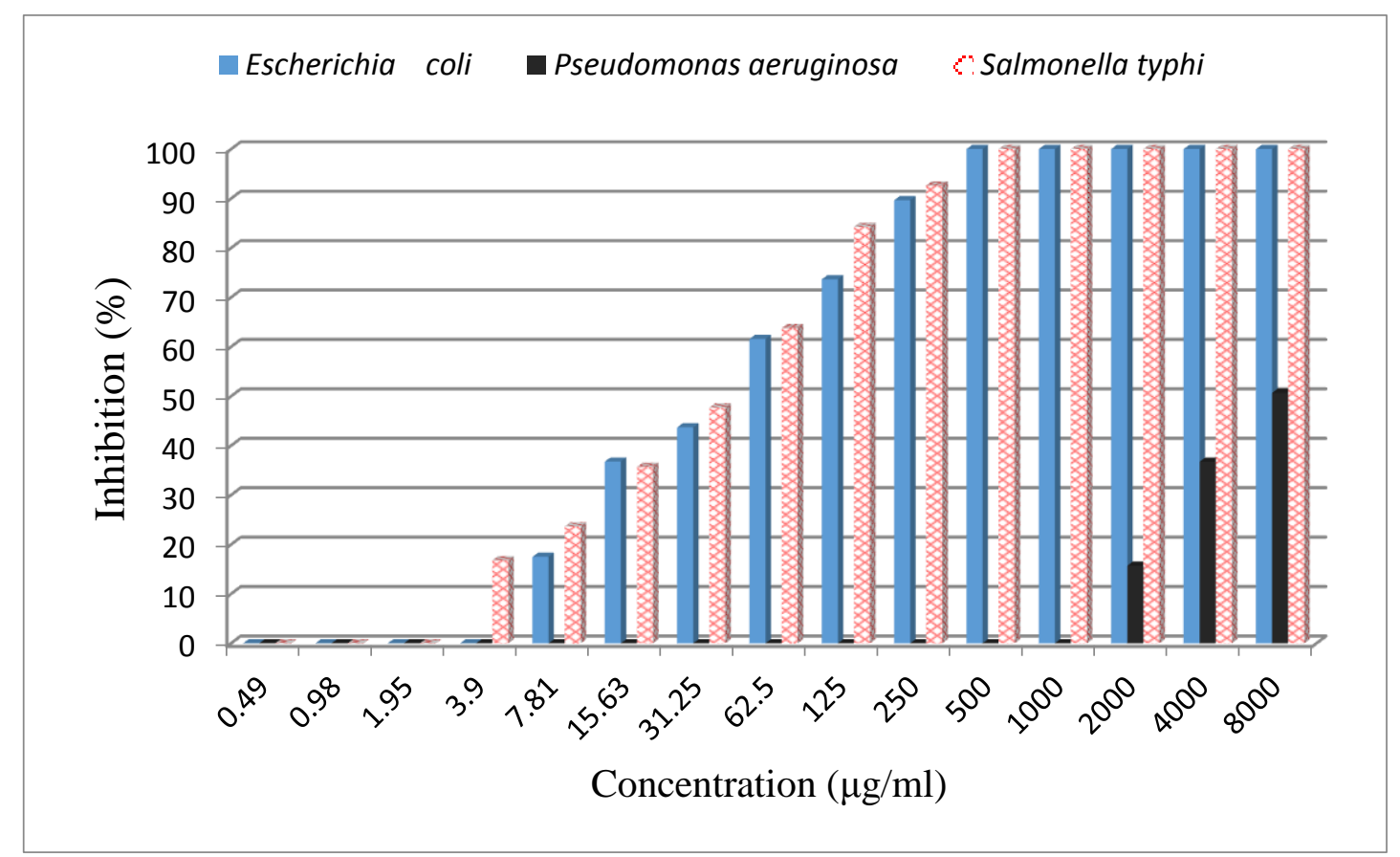

Fig. 1: Antibacterial activity of chitosan nanoparticles against Escherichia coli, Pseudomonas aeruginosa and Salmonella typhi.

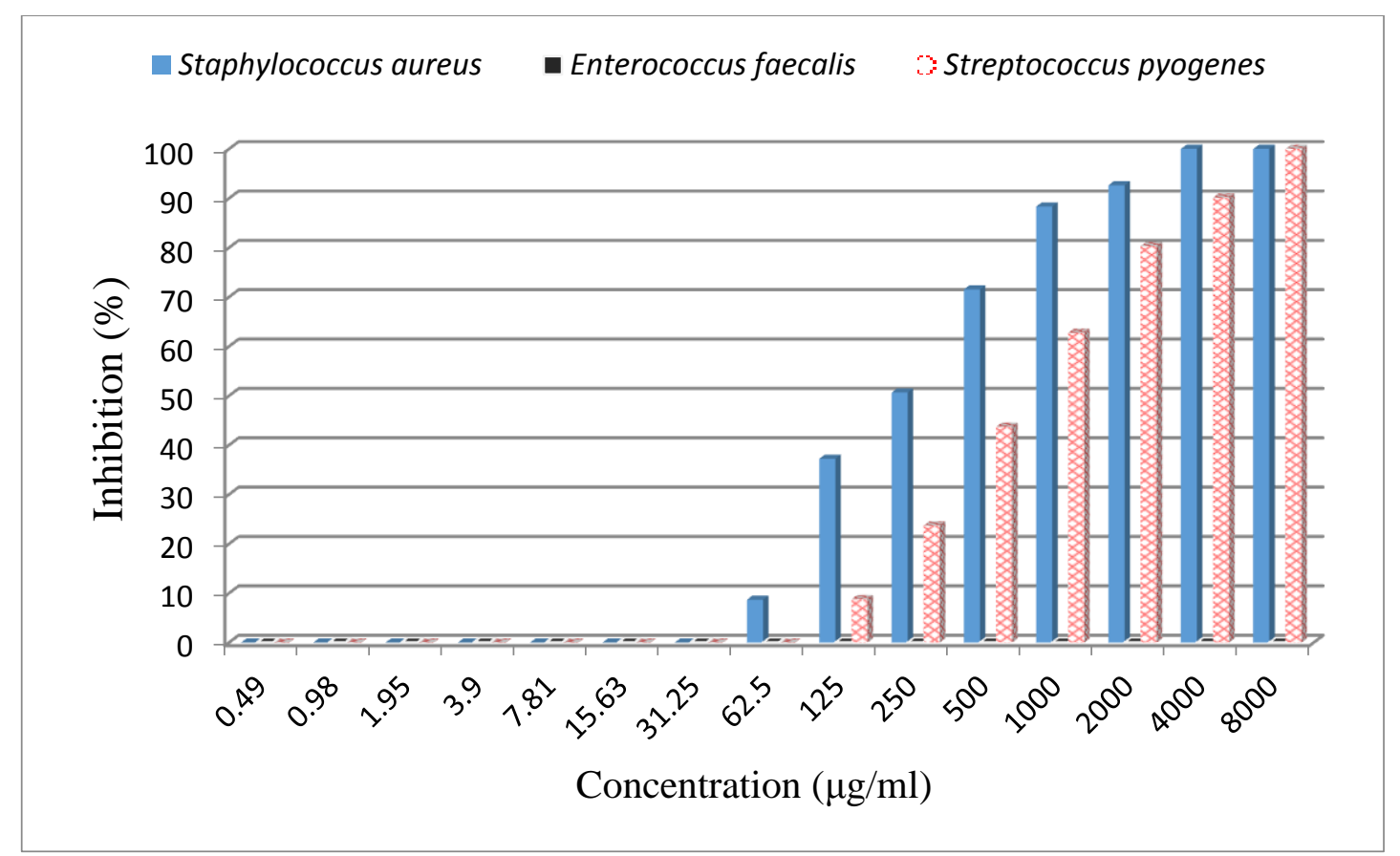

Fig. 2: Antibacterial activity of chitosan nanoparticles against Staphylococcus aureus, Enterococcus faecalis and Streptococcus pyogenes. 


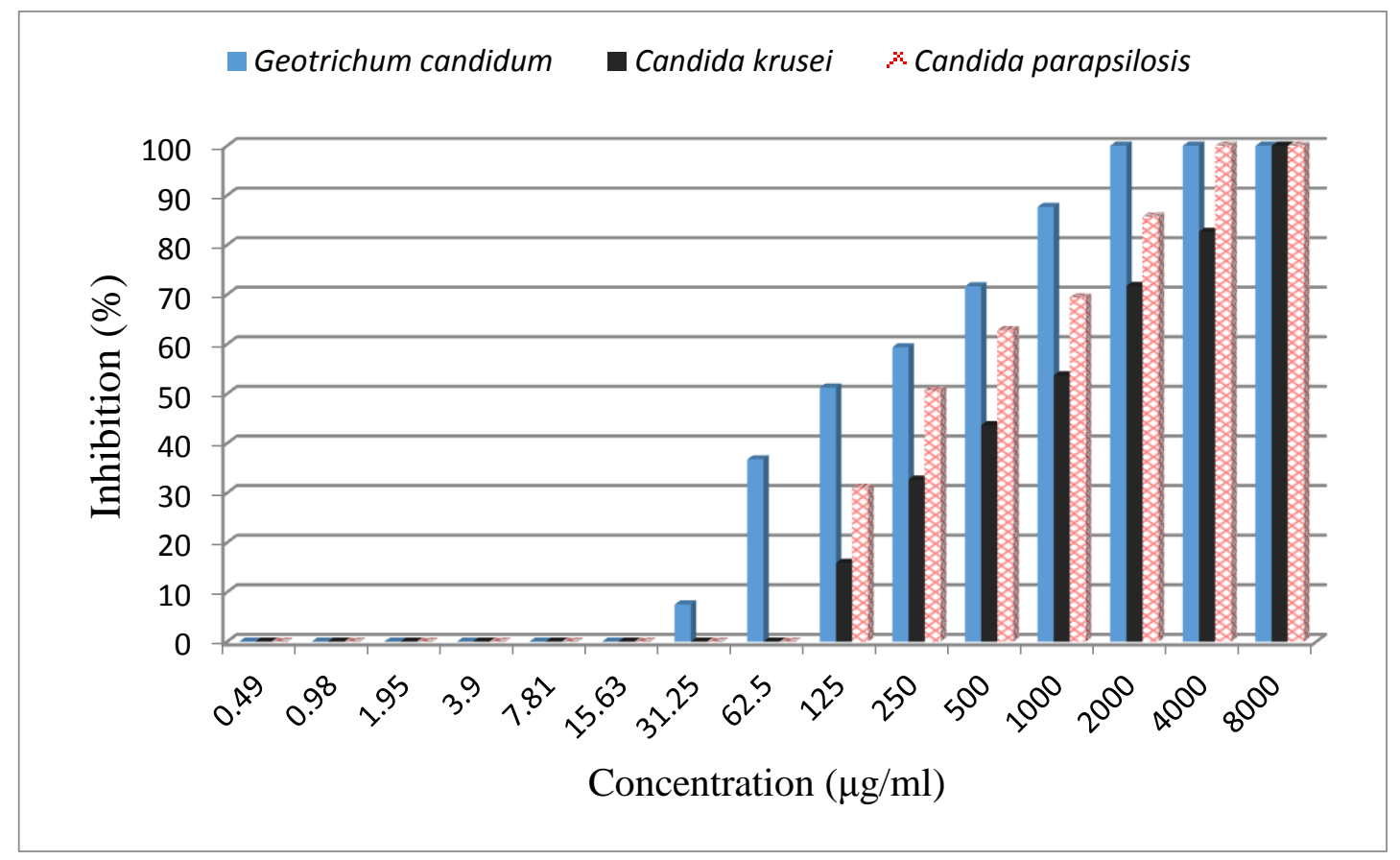

Fig.3: Antifungal activity of chitosan nanoparticles against Geotrichum candidum, Candida krusei and Candida parapsilosis.

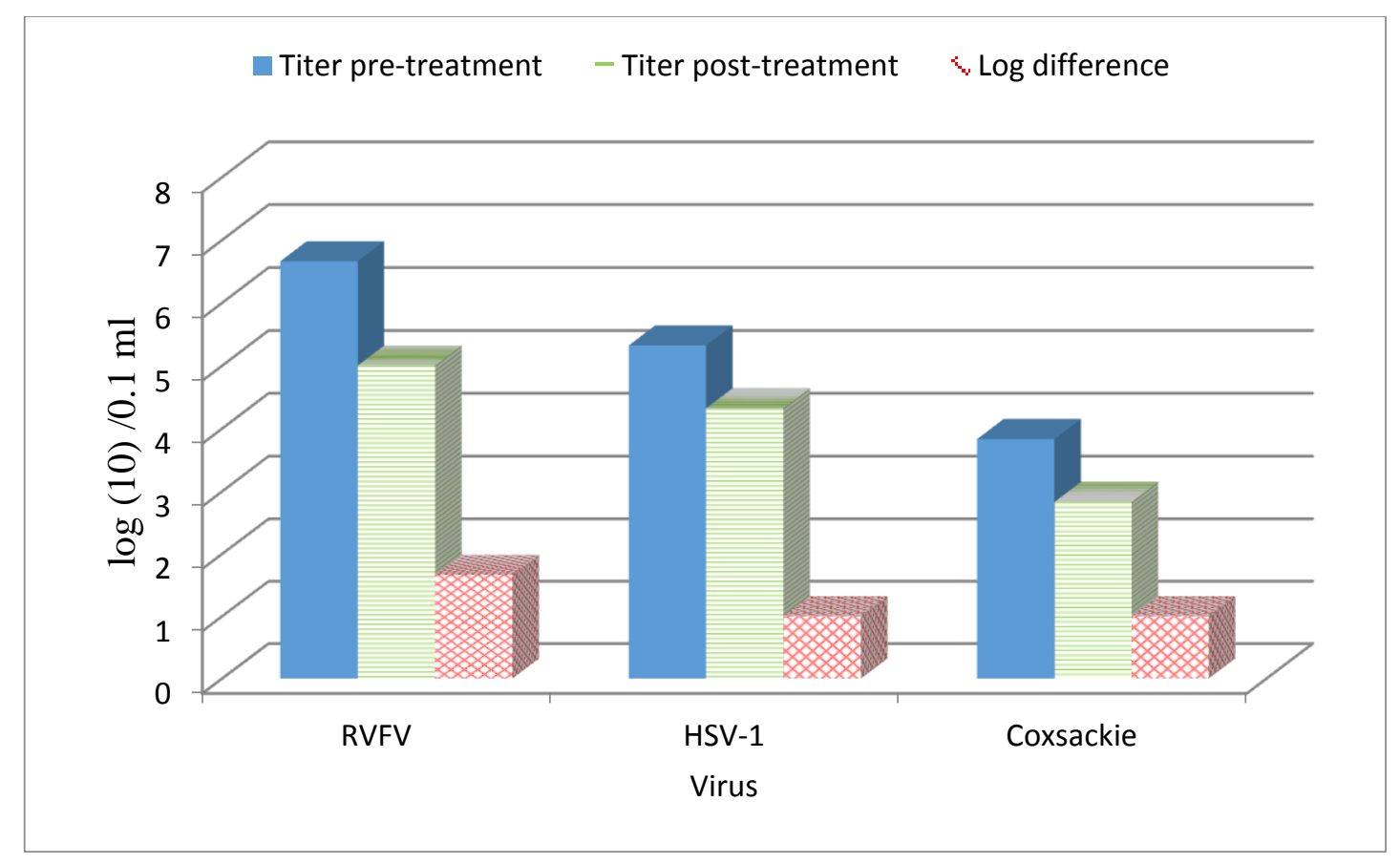

Fig. 4: Antiviral activity of chitosan nanoparticles against Rift Valley Fever (RVFV), Herpes simplex-1 (HSV-1) and Coxsackie viruses. 